\title{
SIGNIFIKANSI DAKWAH INKLUSIF NURCHOLISH MADJID BAGI MASYARAKAT INDONESIA
}

\author{
Zaprulkhan $^{1}$
}

\begin{abstract}
Articulation of religion in the public sphere of Indonesia is still much to be exclusive and puritan, unilateral in monopolizing the truth claims of religious truth, and intolerance towards various religious disagreement. Whereas in the context of a pluralistic Indonesian nation, whether of race, ethnicity, culture, class, and religion, religious messages should be delivered by inclusive proselytizing. Anyone who would articulate religious discourses in the public sphere of Indonesia, should ideally be through inclusive proselytizing. In the context of inclusive proselytizing, Islamic values such as justice (al-'adl), human rights, freedom (Hurriyah), democracy (Shura), universal benevolence (Khoir), egalitarian (Musawah), tolerance (tasamuh), balance (tawazun), social ethics (morals), universal humanity (an-nas), as well as peace and safety contained in the doctrine of principle Islam but those are inclusive. Inclusive priciples could embrace all people regardless of race, culture, race, class, and even religion. This article is going to discuss the significance of Nurcholish Madjid's inclusive proselytizing for pluralistic Indonesian society.
\end{abstract}

Keywords: significance, inclusive proselytizing, the Indonesian nation, pluralistic

\section{A. Pendahuluan}

"Islam artinya pasrah sepenuhnya (kepada Allah), sikap yang menjadi inti ajaran agama yang benar di sisi Allah." "Jadi suatu agama, seperti agama yang dibawa oleh Nabi Muhammad (yang memang secara sadar dari semula disebut agama sikap pasrah sempurna kepada Allah atau al-Islam), adalah tidak unik (dalam arti, tidak berdiri sendiri dan terpisah). Dia berada dalam garis kelanjutan dengan agama-agama lain".

Bila kita hendak mendiskusikan sikap keberagamaan inklusif, maka mau tidak mau sebaiknya kita memulai dengan sikap keberagamaan yang kontradiktif dengan inklusif yakni sikap eksklusif dalam beragama. Eksklusivisme merupakan

\footnotetext{
${ }^{1}$ Dosen tetap Pascasarjana STAIN Syaikh Abdurrahman Siddik Bangka Belitung.

2 Nurcholish Madjid, Pintu-Pintu Menuju Tuhan (Jakarta: Paramadina, 1995), hlm. 2 \& 3.
} 
sebuah paham yang menganggap bahwa hanya pandangan dan kelompoknya yang paling benar, sedangkan kelompok lain dianggap salah. ${ }^{3}$ Sikap eksklusif adalah sikap yang memandang bahwa keyakinan, pandangan, pikiran dan prinsip diri sendirilah yang paling benar, sementara keyakinan, pandangan, pikiran, dan prinsip yang dianut orang lain salah, sesat dan harus diajuhi.

Akibat dari sikap yang demikian, maka mereka tidak mau menerima saran, masukan, dan pemikiran yang berasal dari luar. Dengan demikian dialog yang disandarkan pada kemitraan dan kesederajatan juga yang tidak terjadi. ${ }^{4}$ Pada titik inilah, kita membutuhkan sebuah sikap keberagamaan yang konstruktif positif dalam memandang perbedaan yakni sikap inklusivisme. Inklusivisme merupakan sebuah paham yang mengakui bahwa dalam agama-agama lain terdapat juga suatu tingkat kebenaran, tetapi puncak kebenaran terdapat dalam agama sendiri. $^{5}$

Dalam pemikiran Islam, paham inklusivisme dimulai dengan penggalian pengertian Islam (islam), bukan sebagai organized religion (agama terlembaga), tetapi menggalinya dalam arti ruhani. Islam, artinya pasrah sepenuhnya (kepada Allah). Sikap yang-menurut para pendukung paham inklusif-menjadi inti ajaran agama yang benar di sisi Allah. Karena itu, semua agama yang benar disebut islam. Banyak ayat dalam Al-Qur'an yang menyebutkan bahwa para Nabi dan Rasul terdahulu mengajarkan al-islam ini. Sehingga tidak mengherankan, kalau kemudian dikembangkan suatu teologi Islam inklusif yang didasarkan pada Al-Qur'an. ${ }^{6}$

Sampai disini, rumusan inklusivisme yang digulirkan Cak Nur dalam kutipan awal pembuka tulisan ini menemukan gemanya: Hakikat Islam adalah sebuah sikap kepasrahan dan ketundukan kepada Tuhan Yang Maha Esa yang menjadi inti semua keberagamaan autentik Nabi-Nabi sebelum Nabi Muhammad

\footnotetext{
${ }^{3}$ Zuhairi Misrawi, Al-Qur'an Kitab Toleransi (Jakarta: Fitrah, 2007), hlm. 198.

${ }^{4}$ Abuddin Nata, Peta Keragaman Pemikiran Islam Di Indonesia (Jakarta: Raja Grafindo Persada, 2001),hlm. 42.

${ }^{5}$ Nurcholish Madjid dkk, Fiqih Lintas Agama (Jakarta: Paramadina, 2004), hlm. 64-63 dab 206.

6 Budhy Munawar Rachman, Argumen Islam Untuk Pluralisme (Jakarta: Grasindo, 2010), hlm. 24-25.
} 
Saw. Karena itu semua agama yang benar disebut Islam. Namun wacana inklusif secara doktrinal tersebut, bagi Cak Nur harus diterjemahkan pula pada tataran sosial. Dalam pandangan Cak Nur, sesungguhnya Islam selalu mengungkapkan bahwa kebajikan Islam adalah untuk semesta alam, untuk kebaikan semua orang. Rahmatan lil 'alamin. Jadi bukan untuk kebaikan orang Islam itu sendiri. Itu berarti nilai-nilai Islam bisa dilaksanakan bagi seluruh manusia sehingga yang memanfaatkannya tidak hanya orang Islam itu sendiri, tapi semua orang. Orang Islam sekarang berbicara tentang keadilan, persamaan antar manusia, hak pribadi, yang semuanya ada dalam ajaran Islam namun inklusif. ${ }^{7}$

Melalui kutipan dari Cak Nur pada intro pembuka tulisan ini, kita melihat Cak Nur membingkai Islam secara inklusif dalam dua level: pertama, inklusif secara substantif-doktrinal, dan kedua, inklusif secara substantif-sosial. Keduanya tidak terpisahkan; yang pertama menjadi dasar bagi yang kedua; Dengan kata lain, yang kedua merupakan konsekuensi niscaya dari yang pertama. Pada level kedua inilah, nilai-nilai kebajikan Islam mesti didakwahkan secara inklusif sehingga dapat memberikan manfaat kepada semua orang, kepada seluruh masyarakat Indonesia. Karena itu, dalam uraian selanjutnya, kita akan membahas secara lebih detil dakwah inklusif Islam Cak Nur pada dua level tersebut: yakni inklusif secara substantif-doktrinal dan inklusif secara substantif-sosial, serta diakhiri dengan catatan singkat mengenai signifikansinya bagi masyarakat Indonesia.

\section{B. Inklusif Secara Substantif-Doktrinal}

Ketika berbicara mengenai wacana inklusif, dalam perspektif Cak Nur, kita seyogyanya berangkat dari suatu yang mendasar sekali mengenai makna Islam itu sendiri. Menurut Cak Nur, dari segi tasrifnya, istilah "Islam" adalah mashdar atau kata benda verbal (verbal noun) dari kata kerja aslama-yuslimu yang mengandung makna sikap aktif dari "menyerahkan diri" atau "bersikap

\footnotetext{
7 Nurcholish Madjid, Dialog Keterbukaan (Jakarta: Paramadina, 1998), hlm. 173.
} 
pasrah". Dalam pengertian asal ini, "bersikap pasrah" dalam arti bersikap pasrah kepada Sang Maha Pencipta. ${ }^{8}$

Sebagai mashdar dari kata kerja aslama, istilah Islam juga memiliki arti "mencari salam”, yakni, "kedamaian”, "berdamai”, dan dari semua itu juga menghasilkan pengerian "tunduk", "menyerah", dan "pasrah". Maka agama yang benar disebut "Islam" karena mengajarkan sikap berdamai dan mencari kedamaian melalui sikap menyerah, pasrah dan tunduk patuh kepada Tuhan secara tulus". 9

Berangkat dari pengertian Islam secara generik ini, kemudian dengan merujuk kepada ayat-ayat Al-Qur'an, menurut Cak Nur, sikap pasrah dan tunduk kepada Tuhan secara tulus bukan hanya menjadi tuntunan etis-spiritual bagi manusia, tapi juga merupakan pola wujud (mode of existence) seluruh alam raya beserta isinya. Karena itu, jika manusia diseru untuk memilih sikap hidup tunduk, menyerah dan pasrah kepada Tuhan, yaitu untuk ber-islam, maka tidak lain ialah seruan agar manusia mengikuti pola hidup yang sama dengan pola wujud alam raya. Yang dihasilkan oleh sikap itu tidak saja kedamaian dengan Tuhan, diri sendiri, dan sesama manusia, tetapi juga dengan sesama makhluk, sesama isi seluruh alam raya, dan jagad raya itu sendiri. ${ }^{10}$

Al-Qur'an memberikan berbagai ilustrasi tentang ketundukan, ketaatan, dan kepasrahan alam semesta kepada Tuhan. Beberapa di antaranya adalah:

"Kemudian Dia (Tuhan) bertahta di langit yang berupa kabut, lalu berfirman kepadanya dan kepada bumi: 'Datanglah (kepada-Ku) kamu berdua dengan taat ataupun terpaksa! Keduanya menjawab 'kami datang dengan taat” (QS. Fushshilat 41: 11).

"Matahari dan rembulan (beredar) dengan perhitungan (yang pasti), dan bintang-bintan dan pepohonan semuanya bersujud (kepada-Nya)" (QS. Al-Rahman 55: 5-6).

"Bertasbih kepada-Nya seluruh langit dan bumi, juga mereka yang ada di dalamnya. Tidak ada sesuatu apapun kecuali mesti bertasbih dengan pujian kepada-Nya, namun kamu sekalian (manusia) tidak mengerti tasbih mereka” (QS. Al-Isra' 17: 44)

${ }^{8}$ Komaruddin Hidayat dan Ahmad Gaus AF (ed.), Passing Over (Jakarta: Gramedia Pustaka Utama, 2001), hlm.21.

${ }_{9}$ Nucholish Madjid, Islam Agama Peradaban (Jakarta: Paramadina, 2000), hlm. 219.

${ }^{10}$ Ibid. 
Tergolong "mereka yang ada di dalamnya (di langit dan bumi)" tersebut dalam firman itu ialah umat manusia. Maka sejalan dengan ketentuan Tuhan itu semua, manusia pun bersikap tunduk, patuh dan pasrah atau, sebutlah ber-islam kepada Tuhan. ${ }^{11}$

Selanjutnya, sikap pasrah kepada Tuhan atau berislam ini bukan hanya berlaku bagi umat Nabi Muhammad Saw melainkan juga menjadi sikap keberislaman semua Nabi-Nabi sebelum Nabi Muhammad Saw. Dengan menelusuri ayat-ayat Al-Qur'an, Cak Nur menunjukkan secara substantifdoktrinal bahwa al-Islam atau ajaran pasrah kepada Allah secara suka-rela dan damai adalah ajaran dan agama semua nabi yang diterima dari Tuhan. Tentang alislam sebagai agama para nabi itu secara ringkas dan bersifat mewakili dijelaskan dalam Al-Qur'an dalam rangkaian ajaran Nabi Ibrahim dan pesannya kepada anak-cucunya:

"Siapakah yang merasa tidak senang kepada agama Ibrahim kecuali orang yang membodohi dirinya sendiri!? Kami sungguh telah memilihnya di dunia, dan di akhirat pastilah ia tergolong orang-orang yang saleh. Ketika Tuhannya berfirman kepadanya, 'Pasrahlah engkau!' Ia menjawab 'aku pasrah kepada Tuhan seru sekalian alam". Dan Ibrahim pun berpesan dengan ajaran itu kepada anak-anaknya, begitu pula Ya'qub: 'Wahai anak-anakku, sesungguhnya Allah telah memilihkan untuk kamu ajaran ketundukan (al-din), maka janganlah sampai kamu mati kecuali sebagai orang-orang muslim (pasrah kepada Allah)'. Apakah kamu menjadi saksi saat maut datang kepada Ya'qub, ketika ia bertanya kepada anak-anaknya, "Apa yang kalian sembah setelah aku tidak ada?" Mereka. Ismail dan Ishaq, yaitu Tuhan Yang Maha Esa, dan kami semua orang-orang yang muslim kepadaNya" (QS. Al-Baqarah 2: 130-133)

Demikian pula halnya dengan semua Nabi, dengan berbagai cara dituturkan dalam Al-Qur'an sebagai tokoh-tokoh yang mengajarkan sikap pasrah kepada Tuhan atau al-islam. Dan orang-orang yang menerima dan mengikuti ajaran para nabi itu pun disebut sebagai orang-orang yang muslim. Tentang Nabi Musa, misalnya, Al-Qur'an menuturkan bahwa ia pernah menyeru kepada kaumnya, "Wahai kaumku, jika kamu benar-benar beriman kepada Allah maka

11 Komaruddin, Passing Over, hlm. 7. 
bertawakallah kepada-Nya, kalau memang kamu benar-benar orang-orang yang muslim” (QS. Yunus 10: 84). Sedangkan tentang para ahli sihir yang semula-mula ikut menentang Nabi Musa a.s namun kemudian tunduk dan beriman kepadanya, diceritakan pernah menyatakan kepada Fir'aun:

"Engkau (Fir'aun) tidaklah dendam kepada kamu melainkan hanya karena kami beriman kepada ayat-ayat Tuhan setelah datang kepada kami". "Oh Tuhan kami, limpahkanlah kami ketabahan, dan wafatkanlah kami sebagai orang-orang yang muslim”. (QS. Al-A'raf 7: 126)

Dan berkenaan dengan Nabi Isa a.s al-Masih a.s serta para pengikutnya, Kitab Suci menuturkan sebagai berikut:

"Setelah Isa merasakan adanya sikap menolak (kafir) pada mereka (Bani Israil), ia pun bertanya, "Siapakah yang akan menjadi pendukungku menuju Allah?" al-hawariyun (para pengikut setianya) menyahut, "kami para pendukung Allah, kami beriman kepada Allah, dan saksikanlah bahwa kami adalah orang-orang muslim”. (QS. Al-Imran 3: 52 )

"Dan ketika Aku mewahyukan kepada al-hawariyun (para pengikut setia Nabi Isa al-Masih), "Berimanlah kamu sekalian kepada-Ku dan kepada utusan-Ku!" Mereka menjawab, "kami beriman, dan saksikanlah bahwa kami adalah orang-orang muslim”. (QS. AlMaidah 5: 111)

Karena seluruh jagad raya berserta isinya melaksanakan al-islam (ajaran tunduk-patuh serta taat dan pasrah dengan tulus kepada Allah) dan karena sekalian para nabi mengajarkan al-islam, maka dapat dimengerti mengapa Allah, Tuhan Yang Maha Esa, tidak menerima agama atau din (ajaran ketundukan) selain dari al-islam. Hal ini dengan jelas sekali ditegaskan dalam sebuah firman:

"Apakah mereka hendak menganut selain ajaran tunduk kepada Allah (din Allah, "agama Allah”)!? Padahal telah pasrah (aslama) kepada-Nya meraka yang ada di seluruh langit dan bumi, dengan taat ataupun terpaksa”.

"Katakan (Muhammad), "kami beriman kepada Allah dan kepada ajaran yang diturunkan kepada kami, serta kepada ajaran yang diturunkan kepada Ibrahim, Ismail, Ishaq, Ya'qub, al-asbath (nabinabi Bani Israil), juga kepada ajaran yang diberikan kepada Musa dan Isa dan para nabi yang lain dari Tuhan mereka. Kami tidak membeda-bedakan antar seorang pun dari mereka, dan kami semua pasrah (muslim) kepada-Nya”. 
"Barang siapa menganut suatu din (ajaran ketundukan) selain alislam (ajaran pasrah, pasrah kepada Allah) maka tidak akan diterima daripadanya, dan dia itu di akhirat termasuk golongan yang menyesal (merugi)”. (QS. Al-Imran 3: 52 )

Bagi Cak Nur, dari deretan tiga ayat suci itu, jelas sekali bahwa yang dimaksud dengan Islam - atau lebih tepatnya sebagai istilah dengan makna generiknya, al-islam-ialah sikap tunduk-patuh dan taat-pasrah kepada Tuhan yang meliputi seluruh alam semesta. Ajaran itu kemudian dibawakan oleh para nabi-yang umat manusia harus menerima semua mereka itu dan beriman kepada ajaran mereka-menjadi “agama”. Dan al-islam universal inilah yang merupakan satu-satunya ajaran ketundukan atau din yang dibenarkan dan diterima oleh Tuhan Yang Maha Esa. ${ }^{12}$

Secara analisis, dari tiga ayat suci tersebut, kita dapat menguraikan pengertian/makna Islam dalam tiga aspek. Pertama, dikaitkan dengan pola wujud seluruh alam raya, khususnya makhluk-makhluk yang menjadi penghuninya, yaitu bahwa semua yang ada ini tunduk-patuh dan pasrah kepada Tuhan Maha Pencipta, baik secara suka-rela ataupun terpaksa; Kedua, dikaitkan dengan semua agama yang diturunkan kepada para Nabi dan Rasul sebelum Nabi Muhammad Saw, dan beliau ini serta para pengikut beliau diperintahkan untuk menyatakan percaya atau beriman kepada semua itu tanpa membeda-bedakan satu dari yang lain, dan semua para Nabi serta pengikut mereka itu adalah sama-sama menempuh sikap hidup pasrah kepada Tuhan, yakni, muslimun. Ketiga sebagai kesimpulan dan penegasan berdasarkan itu semua, maka barang siapa menganut selian islam sebagai pola keagamaannya, ia tidak akan diterima. ${ }^{13}$

Konsekuensinya, inti serta pangkal al-Islam itu sepanjang masa ialah iman kepada Tuhan Yang Maha Esa, yang dalam bahasa Arab disebut Allahberasal dari Al-Ilah yang berarti, Tuhan yang sebenarnya, yaitu Tuhan Yang Maha Esa. (Dari segi kebahasaan, perkataan Arab Allah atau Al-Ilah itu padanan Inggrisnya ialah the God). Iman kepada Allah itu sendiri harus dimulai dengan

\footnotetext{
${ }^{12}$ Ibid., hlm. 17.

${ }^{13}$ Madjid, Islam Agama Peradaban, hlm. 219-220.
} 
pernyataan penolakan kepada sesembahan-sesembahan palsu dalam sistem kepercayaan-kepercayaan palsu. ${ }^{14}$

Untuk memperkuat argumentasi tentang inti ajaran semua Nabi dan Rasul ini, Cak Nur mengutip pendapat Ibn Taymiyah sebagai berikut:

Oleh karena itu pangkal al-islam ialah persaksian bahwa "Tidak ada suatu tuhan apapun selain Allah, Tuhan, yang sebenarnya", dan persaksian itu mengandung makna penyembahan hanya kepada Allah semata dan meninggalkan penyembahan kepada selain Dia. Inilah al-islam al- 'amm (Islam umum, universal) yang Allah tidak menerima ajaram ketundukan selain daripadanya.

Maka semua Nabi itu dan para pengikut mereka, seluruhnya disebut oleh Allah Ta'ala bahwa mereka adalah orang-orang muslim. Hal ini menjelaskan bahwa firman Allah Ta'ala, "Barang siapa menganut suatu din selain al-islam maka tidak akan diterima daripadanya dan di akhirat dia termasuk yang merugin" (QS, 3: 85), dan firman-Nya, "Sesungguhnya al-din di sisi Allah ialah alislam" (QS. 3: 19), tidaklah khusus tentang orang-orang (masyarakat) yang kepada mereka Nabi Muhammad Saw diutus, melainkan hal itu merupakan suatu hukum umum ( $\mathrm{hukm}$ 'amm, ketentuan universal) tentang manusia masa lalu dan manusia kemudian hari. $^{15}$

Namun Cak Nur menegaskan, di sini perlu diingatkan bahwa sekalipun para Nabi mengajarkan pandangan hidup yang disebut al-islam, tidaklah berarti bahwa mereka dan kaumnya menyebut secara harfiah ajaran mereka al-islam dan mereka sendiri sebagai orang-orang muslim. Sebab itu semua adalah peristilahan dalam bahasa Arab, sementara para Nabi dan Rasul itu, sebagaimana disebutkan dalam Al-Qur'an, dibangkitkan Allah dengan menggunakan bahasa kaumnya masing-masing. Karena itu penyebutan para nabi dan rasul itu beserta para pengikut mereka sebagai orang-orang muslim dan ajaran atau agama mereka sebagai al-islam tetap benar dan dibenarkan, hanya saja sedikit melibatkan masalah kebahasaan. ${ }^{16}$

Lagi-lagi dengan mengutip pandangan Ibn Taymiyah, Cak Nur memberi penjelasan yang menarik tentang hal ini, dengan membedakan antara "Islam

\footnotetext{
14 Komaruddin, Passing Over, hlm. 17.

${ }^{15}$ Ibid., hlm. 17-18.

${ }^{16}$ Ibid., hlm. 18.
} 
khusus" (al-islam al-khashsh) dan "Islam umum" (al-islam al-'amm) sebagai beikut:

Manusia berselisih tentang orang terdahulu dari kalangan umat Nabi Musa dan Nabi Isa, apakah mereka itu orang-orang muslim? Ini adalah suatu perselisihan kebahasaan. Sebab "Islam khusus" (al-islam al-khashsh) yang dengan ajaran itu Allah mengutus Nabi Muhammad Saw yang mencakup syariat Al-Qur'an tidak ada yang termasuk ke dalamnya selain umat Muhammad Saw. Dan al-islam sekarang secara keseluruhan bersangkutan dengan hal ini. Adapun "Islam umum" (al-islam al- 'amm) yang bersangkutan dengan setiap syariat yang dengan itu Allah membangkitkan seorang Nabi maka bersangkutan dengan islam-nya setiap umat yang mengikuti seorang Nabi dari para Nabi itu. ${ }^{17}$

Jadi makna Islam di sini bukan lagi hanya berkonotasi sebagai nama agama secara institusional, melainkan lebih dari itu, sebagai sebuah sikap ketundukan, kepatuhan, dan kepasrahan tulus yang dilakukan setiap orang dengan penuh penghayatan secara personal. Dalam konteks inilah, di samping makna Islam secara legal-formal yang telah membentuk institusional agama Islam, Cak Nur juga ingin membawa makna Islam secara substantif-doktrinal yang bercorak inklusif: suatu sikap ketundukan dan kepasrahan secara tulus kepada Tuhan Yang Maha Esa yang bisa dilakukan oleh setiap orang tanpa memandang latarbelakang budaya, bahasa, etnis, ras, bangsa, dan agama formalnya.

\section{Inklusif Secara Substantif-Sosial}

Berangkat dari pembacaan terhadap makna Islam secara substantifdoktrinal yang memiliki karakter inklusivistik, Cak Nur kemudian hendak membawa pesan-pesan kebajikan Islam ke dalam tataran publik dalam semangat inklusivistik pula. Semua nilai-nilai kebajikan yang berada dalam agama Islam ketika hendak memasuki ruang publik masyarakat Indonesia yang pluralistik, idealnya semua nilai-nilai kebajikan Islam tersebut mesti melalui proses substansiasi dan rasionalisasi terlebih dahulu ke dalam istilah yang bersifat inklusivistik, yakni mampu merangkul, menyentuh, dan meliputi semua lapisan masyarakat Indonesia.

17 Ibid., hlm. 18-19. Bandingkan dengan pandangan pakar Al-Quran, Al-Raghif alIsfahani, dalam karyanya Mufradat al-Quran (Beirut: Dar al-Syamiyah, 1996), h. 423. 
Meminjam konsep cendekiawan besar kita, Kuntowijoyo, semua komponen kebajikan yang berada dalam agama Islam harus ditransformasikan terlebih dahulu ke dalam terminologi yang objektif dengan tujuan agar dapat diterima oleh semua pihak yang berbeda yang berada dalam ruang publik Indonesia. Inilah yang disebut oleh Kuntowijoyo sebagai objektifikasi. ${ }^{18}$

Bagi Cak Nur, nilai-nilai prinsip Islam yang dapat dirumuskan secara inklusivistik sangat banyak mencakup keadilan, persamaan antar manusia, hak pribadi, kemakmuran, demokrasi, dan lain-lain. ${ }^{19}$ Dalam konteks dakwah inklusif, nilai-nilai Islam seperti keadilan ( $a l$-' $a d l)$, hak asasi manusia, kebebasan (hurriyah), demokrasi (syuro), kebajikan universal (khoir), egaliter (musawah), toleransi (tasamuh), keseimbangan (tawazun), etika sosial (akhlak), kemanusiaan universal (an-nas), serta kedamaian dan keselamatan (salam) terdapat dalam doktrin prinsipil Islam namun bersifat inklusif, yakni mampu merangkul semua orang tanpa memandang suku, budaya, ras, golongan, bahkan agamanya.

Spirit inklusivistik secara substantif-sosial itu, bagi Cak Nur, memang mesti berangkat dari wacana keagamaan ataupun tradisi keagamaan kita. Kita bisa menyimak argumentasi inklusivistik Cak Nur berikut ini:

"Memang dalam keadaan aneka ragam hakikat kebangsaan kita yang demikian besar sulit sekali bagi kita menemukan kesepakatan penuh dalam segala hal. Tetapi setidaknya kita harus berusaha dengan cukup kesungguhan untuk menemukan kosa kata yang sama atau mendekatkan satu sama lain dalam pandangan hidup umum. Hal itu berarti bahwa masing-masing harus berusaha menemukan dalam khazanah budaya atau sejarahnya sesuatu yang secara metafisis memperkuat wawasan bersama dalam kehidupan umum itu, dengan menggali kembali bibit-bibit atau potensipotensi dalam khazanah itu, bukan sekedar perubahan-perubahan eksternalnya; mempelajari kembali contoh-contoh sejarah, bukan sekedar pengalaman-pengalaman kontemporer. Kemudian semuanya itu diangkat ke daratan generalisasi yang cukup tinggi sehingga menjadi bersifat universal-inklusif, berlaku untuk semua;

18 Kuntowijoyo, Islam Sebagai Ilmu (Jakarta: Teraju, 2004), h. 76; Kuntowijoyo, Identitas Politik Umat Islam (Bandung: Mizan, 1997), h. 68-71.

${ }^{19}$ Madjid, Dialog Keterbukaan, hlm. 173. 
tidak bersifat partikular-eksklusif, yang berlaku hanya untuk golongan khusus tertentu semata".

Meminjam kosa kata dari Jurgen Habermas, konsep-konsep keagamaan yang sudah bersifat universal-inklusif itu memasuki status epistemis yang dapat diterima oleh semua warga negara yang berbeda. Menurut habermas, berbagai kelompok agama mesti menerjemahkan kontribusi-kontribusi (prinsipprinsip/nilai-nilai kebajikan agama) dari bahasa religius partikular mereka ke dalam bahasa yang dapat diterima oleh publik karena dalam deliberasi resmi parlemen, kementerian, peradilan dan birokrasi hanyalah 'alasan-alasan sekular' yang dapat diperhitungkan. Karena itu keyakinan-keyakinan religius harus dijelaskan secara rasional, sehingga memiliki suatu 'status epistemis' yang dapat diterima oleh para warga lainnya, entah itu orang yang beragama lain atau yang sekular. ${ }^{21}$ Mari kita lihat beberapa contoh wacana dakwah inklusif Cak Nur tentang keadilan, kemanusiaan universal, kebebasan, dan demokrasi.

\section{Keadilan}

Ketika berbicara tentang keadilan, Cak Nur, sebagaimana kebiasaannya, selalu berangkat dari prinsip-prinsip fundamental yang diajarkan Al-Qur'an, lalu dikontekstualisasikan secara sosial bagi masyarakat Indonesia. Menurut Cak Nur, dalam tatacara pergaulan sesama manusia yang berbentuk masyarakat atau negara, mungkin tidak ada prinsip atau pandangan dasar yang sedemikian didambakan umat manusia sepajang sejarahnya seperti keadilan. Istilah "adil” yang kita pinjam dari bahasa Arab itu mempunyai makna dasar "tengah" atau "seimbang". Maka pikiran dasar keadilan ialah keseimbangan (al-Mizan), yaitu sikap tanpa berlebihan, baik ke kanan atu ke kiri. Karena itu kemampuan berbuat adil senantiasa dikaitkan dengan kearifan atau wisdom, dalam dalam bahasa Arab disebut hikmah, suatu kualitas pribadi yang diperoleh disebabkan adanya pengetahuan yang menyeluruh dan seimbang (tidak pincang atau parsial) tentang suatu perkara. Oleh karena itu, keadilan di-ta'rif-kan sebagai "meletakkan sesuatu

\footnotetext{
${ }^{20}$ Nurcholish Madjid dalam “Mewujudkan Masyarakat Madani di Era Reformasi” Jurnal Titik Temu Vol. 1 Nomor 2, Januari-Juni 2009, hlm. 20-21.

${ }^{21}$ F. Budi Hardiman, Demokrasi Deliberatif (Yogyakarta: Kanisius, 2009), hlm 158-159.
} 
pada tempatnya", dan sebaliknya ke-zalim-an sebagai "meletakkan sesuatu tidak pada tempatnya". 22

Ketika berbicara tentang keadilan, pertama-tama Cak Nur menghubungkannya dengan hukum kosmos, sebagai ketetapan Allah. Bagi Cak Nur, yang amat menarik berkenaan dengan keadilan ini ialah bagaimana dalam Al-Qur'an hal itu dikaitkan dengan hukum ketetapan Allah sebagai kosmos atau alam raya ciptaan-Nya. Kemudian perintah Allah untuk menegakkan keadilan pun dikaitkan dengan hukum alam raya itu. Maka melanggar prinsip keadilan berarti melanggar hukum kosmos, sehingga dapat kita bayangkan betapa besar dosanya. Allah Swt beefirman:

"Dan langitpun ditinggikan oleh-Nya, dan ditetapkan-Nya (hukum) Keseimbangan (al-Mizan). Maka hendaknya kamu (umat manusia) jangalah melanggar (hukum) Keseimbangan itu, serta tegakkanlah timbangan dengan jujur, dan janganlah merugikan (hukum) keseimbangan”. (QS. Ar-Rahman 55: 7-9)

Jadi ditegaskan bahwa langit, yakni seluruh alam raya, terwujud dengan adanya hukum Keseimbangan. Kita tidak boleh melanggar hukum itu. Maka dalam bentuk yang paling nyatapun, melakukan timbangan (al-wazn), kita harus melakukannya dengan penuh kejujuran. Bertindak tidak jujur dalam timbangan itu melanggar hukum keseimbangan kosmos. ${ }^{23}$

Berhubungan dengan ayat di atas, Cak Nur menguraikan pandangan pakar tafsir A-Qur'an terkenal, yaitu al-Zamakhsyari yang menyatakan bahwa perkataan 'timbangan' atau al-wazn dalam firman Allah itu dapat diartikan secara metaforis. Dalam uraian ini yang dimaksud dengan 'timbangan' itu ialah setiap rasa keadilan yang meliputi seluruh kegiatan hidup kita, baik yang lahir maupun yang batin. Maka perintah Allah agar kita 'melakukan timbangan secara jujur itu' ialah perintah agar kita dalam segala perkara senantiasa memperhatikan rasa keadilan dan kejujuran. Jika tidak, maka berarti kita telah melanggar, merusak, dan merugikan hukum seluruh alam raya. Ini berarti bahwa reaksi keberatan terhadap tindakan tidak adil dan tidak jujur kita itu tidak hanya datang dari orang

22 Madjid, Pintu-Pintu Menuju Tuhan, hlm. 40.

${ }^{23}$ Ibid., hlm. 40-41. 
yang merugikan kita saja, tetapi dari seluruh alam raya. ${ }^{24}$ Sebab keadilan merupakan sebuah hukum kosmos.

Berangkat dari prinsip fundamental tersebut, Cak Nur kemudian menurunkan makna keadilan sebagai sunatullah dalam kehidupan sosial kemasyarakat umat manusia. Bagi Cak Nur, hakikat dasar kemanusiaan, termasuk kemestian menegakkan keadilan, merupakan bagian dari sunatullah, karena adanya fitrah manusia dari Allah dan perjanjian primordial antara manusia dan Allah. Sebagai sunatullah, kemestian menegakkan keadilan adalah kemestian yang merupakan hukum yang obyektif, tidak tergantung kepada kemauan pribadi manusia siapapun juga, dan immutable (tidak akan berubah). Ia disebut dalam AlQur'an sebagai bagian dari hukum kosmis, yaitu hukum keseimbangan (al-mizan) yang menjadi hukum jagad raya atau universe.Karena hakikatnya yang objektif atau immutable itu maka menegakkan keadilan akan menciptakan kebaikan, siapapun yang melaksanakannya, dan pelanggaran terhadapnya akan mengakibatkan malapetaka, siapapun yang melakukannya. ${ }^{25}$

Dengan kata lain, melanggar keadilan, yaitu perbuatan zalim, adalah sebuah dosa kosmis (melanggar aturan jagad raya atau alam semesta), sebuah dosa yang amat besar, dan bukan sekedar dosa pribadi. Karena itu ancaman Allah untuk menghancurkan suatu negara, bangsa, masyarakat, umat, dan lain-lain, disangkutkan dengan kezaliman sosial. Masyarakat yang tidak mewujudkan keadilan akan dihancurkan oleh Allah, tanpa peduli apakah masyarakat itu secara formal mengaku menganut ajaran yang benar atau tidak (lihat QS. 16: 16, dan 47: 38). Berdasarkan itu maka Ibn Taymiyyah mengatakan bahwa keadilan adalah aturan segala sesuatu (nizham-u kull-I syai'), sebagai hukum ketetapan Allah (sunatulah) yang tidak akan berubah atau berganti, yang objektif (berlaku kepada siapa saja tanpa memandang posisi dan paham pribadinya). Ia kutip sebuah ungkapan bijaksana (hikmah):

"Tuhan mendukung kekuasaan yang adil meskipun kafir, dan tidak mendukung kekuasaan yang zalim meskipun Islam", dan, "Dunia

24 Ibid., hlm. 41.

25 Ibid., hlm. 84. 
akan tetap bertahan dengan keadilan sekalipun kafir, dan tidak akan bertahan dengan kezaliman sekalipun Islam". ${ }^{26}$

Dengan semua argumentasi di atas, Cak Nur telah berupaya membingkai makna keadilan secara inklusivistik: bahwa konsekuensi keadilan berlaku bagi semua orang, baik yang bersifat positif maupun negatif, tanpa mamandang latar belakang status sosial, suku, ras, etnis, golongan, bangsa, paham, keyakinan, dan bahkan agamanya sekalipun. Siapa saja yang menunaikan keadilan dalam dimensi kehidupan individual dan sosial, mereka akan sukses dan ruang publik kehidupan sosial yang damai akan tetap eksis. Namun siapa saja yang melanggar keadilan dalam dimensi kehidupan individual dan sosial, satu waktu mereka akan gagal dan ruang publik kehidupan sosial akan chaos, anarkis, dan tidak menutup kemungkinan akan kehilangan eksistensinya.

\section{Kemanusiaan Universal}

Ketika berbicara tentang nilai universal seorang manusia, Cak Nur mengajak kita untuk melihatnya melalui perspektif ketuhanan yang sangat menghargai harkat dan martabat seorang manusia. Dalam hal ini, Cak Nur menayangkan sebuah postulat dari kitab suci yang sangat menarik untuk kita renungkan:

\section{"Dan sesungguhnya telah Kami muliakan anak-anak Adam, Kami angkat mereka di daratan dan di lautan, Kami beri mereka rezeki dari yang baik-baik dan Kami lebihkan mereka dengan kelebihan yang sempurna atas kebanyakan makhluk yang telah Kami ciptakan". (QS. 17: 70). ${ }^{27}$}

Dalam ayata ini, Allah memuliakan manusia karena manusia adalah makhluk unik yang memiliki kehormatan dalam kedudukannya sebagai manusia-baik ia taat beragama maupun tidak. Dengan bersumpah sambil mengukuhkan pernyataan-Nya dengan qad, ayat ini menyatakan bahwa dan Kami, yakni Allah bersumpah bahwa sesungguhnya telah Kami muliakan anak

\footnotetext{
26 Nurcholish Madjid, Islam Kerakyatan Dan Keindonesiaan (Bandung: Mizan, 1996), hlm. 20 .

27 Nurcholish Madjid, Pesan-Pesan Takwa (Jakarta: Paramadina, 2000), hlm. 74.
} 
сиси Adam, dengan bentuk tubuh yang bagus, kemampuan berbicara dan berpikir, serta pengetahuan dan Kami beri juga mereka kebebasan memilah dan memilih. ${ }^{28}$

Dalam perspektif tafsir, ada perbedaan antara fadhdhalna dan karramna. Yang pertama terambil dari kata $f a d h l$, yakni kelebihan, dan ini mengacu kepada 'penambahan' dari apa yang sebelumnya telah dimiliki secara sama oleh orangorang lain. Rezeki misalnya dijamin dan dianugerahkan Allah kepada semua makhluk. Kelebihan rezeki kepada seseorang menjadikan ia memiliki rezeki melebihi dari rezeki yang diberikan-Nya kepada orang lain, dan ini mengakibatkan terjadinya perbedaan antara seseorang dengan yang lain dalam bidang rezeki.

Adapun yang kedua, yakni karramna, maka seperti dikemukakan di atas, ia adalah anugerah berupa keistimewaaan yang sifatnya internal. Dalam konteks ayat ini, manusia dianugerahi Allah keistimewaan yang tidak dianugerahkan-Nya kepada selainnya dan itulah yang mejadikan manusia mulia serta harus dihormati dalam kedudukannya sebagai manusia. Anugerah-Nya itu untuk semua manusia dan lahir bersama kelahirannya sebagai manusia, tanpa membedakan seseorang dengan yang lain. Inilah yang menjadikan Nabi Muhammad Saw berdiri menghormati jenazah seorang Yahudi, yang ketika itu sahabat-sahabat Rasul Saw menanyakan sikap beliau itu, Nabi Saw menjawab: "Bukankah yang mati itu juga manusia?"

Ayat di atas tidak menjelaskan bentuk kehormatan, kemuliaan dan keistimewaan yang dianugerahkan Allah kepada anak cucu Adam a.s. Itu agaknya untuk mengisyaratkan bahwa kehormatan tersebut banyak dan ia tidak khusus untuk satu ras atau generasi tertentu, tidak juga berdasar agama atau keturunan, tetapi dianugerahkan untuk seluruh anak cucu Adam a.s sehingga diraih oleh orang perorang, pribadi demi pribadi. ${ }^{29}$ Senada dengan Quraish Shihab, bagi Cak Nur ayat di atas menganjurkan kita untuk menghargai manusia seperti apa adanya,

${ }^{28}$ M. Quraish Shihab, Tafsir Al-Misbah Vol. 7 (Jakarta: Lentera Hati, 2002), hlm. 511.

29 Ibid., hlm. 513. 
sebagaimana Allah menghargai, menghormati, dan memuliakan manusia melalui titah sakral ayat tersebut. ${ }^{30}$

Selanjutnya, menurut Cak Nur, ada penegasan pula dalam Al-Qur'an bahwa berbuat baik kepada satu orang memiliki nilai yang sama dengan berbuat baik kepada seluruh umat manusia. Penegasan ini merupakan kesimpulan dari penuturan tentang pembunuhan Qabil terhadap Habil; keduanya adalah anak Nabi Adam a.s. Penyebab pembunuhan itu adalah dengki atau iri hati, karena persembahan korban dari Habil diterima Tuhan sementara persembahan korban Qabil ditolak. Padahal alasan penerimaan itu adalah Habil melakukan korban secara ikhlas, sedangkan Qabil tidak. Maka Qabil pun membunuh Habil. AlQur'an menegaskan:

"Karena itu Kami tentukan kepada Bani Israil: 'Barang siapa membunuh orang yang tidak membunuh orang lain atau membuat keruskan di muka bumi, maka ia seolah membunuh semua orang; dan barang siapa menyelamatkan nyawa seorang, maka ia seolaholah menyelamatkan nyawa semua orang”. (QS. 5: 32)

Menurut Cak Nur, ayat ini penting sekali sebagai refleksi atau renungan karena ia tidak pernah menjadi doktrin Islam. Artinya, tidak pernah dielaborasi di dalam teologi, syariat, dan sebagainya. Padahal Al-Qur'an dengan jelas menyatakan bahwa setiap pribadi mempunyai nilai kemanusiaan universal, sehingga kejahatan pada seseorang, tidak pernah merupakan kejahatan pribadi tetapi kejahatan kemanusiaan universal. Sebaliknya, kebaikan kepada seseorang juga tidak pernah merupakan sekedar kebaikan kepada seorang pribadi atau individu tetapi kebaikan kepada kemanusiaan universal. ${ }^{31}$

Dengan demikian, meskipun Cak Nur berangkat dari noktah-noktah ayat Al-Qur'an secara spesifik, namun ia membaca ayat-ayat tersebut dengan spirit inklusivistik: bahwa kemuliaan seorang manusia, siapapun orangnya, bukan didasarkan pada latar belakang status sosial dan ekonominya, bukan karena faktor kekayaan dan keturunannya, bukan karena faktor etnis dan rasnya, bukan karena faktor bahasa dan budayanya, bukan pula karena faktor keyakinan dan agamanya;

\footnotetext{
${ }^{30}$ Madjid, Pesan-Pesan Takwa, hlm. 73-74.

31 Budhy Munawar Rachman (peny.), Ensiklopedi Nurcholish Madjid Vol 3 (Jakarta: Paramadian, 2006), hlm. 2197-2198.
} 
melainkan karena berpijak pada sesuatu yang amat transparan namun subtil yakni sosok seorang manusia itu sendiri apa adanya. Itulah perspektif inklusivistik kemanusiaan universal.

\section{Kebebasan}

Dalam perspektif Cak Nur, kebebasan merupakan sesuatu yang sangat asasi sekali dan mesti dimiliki oleh setiap manusia. Cak Nur memulai pembahasan tentang kebebasan seorang manusia dengan berpijak pada sesuatu yang prinsip sekali yakni terletak pada hati nurani setiap manusia. Dalam hal ini, Cak Nur mengutip beberapa ayat Al-Qur'an yang relevan:

"Demi jiwa dan demi Dia yang telah menyempurnakannya, kemudian Dia ilhamkan kepada jiwa itu (pengetahuan tentang) kejahatan dan ketakwaannya. Sungguh beruntung siapa saja yang menjaga kesuciannya, dan sungguh merugi siapa saja yang mengotorinya" (QS. 9: 7-10). ${ }^{32}$

Bagi Cak Nur, dengan ayat ini, manusia telah dilengkapi oleh Tuhan dengan jiwa, sanubari, atau kalbu yang bersifat terang atau cahaya (nurani), sebagai modal primordial (artinya dibawa sejak lahir, malah sebelum lahir) untuk menerangi hidupnya. Sanubari atau hati nurani merupakan modal primordial setiap orang yang dianugerahkan oleh Tuhan kepada mereka agar dapat secara naluriah mengetahui antara yang benar dan salah, baik dan buruk. ${ }^{33}$

Berdasarkan prinsip-prinsip tersebut, setiap manusia mengasumsikan kebebasan diri pribadinya. Dengan kebebasan inilah manusia menjadi makhluk moral yakni makhluk yang bertanggung jawab sepenuhnya atas segala perbuatan yang dipilihnya dengan sadar, yang saleh maupun yang jahat, yang baik maupun yang buruk, dengan akibat kebahagiaan atau kesengsaraan. ${ }^{34}$ Karena itu, menurut Cak Nur, kehidupan yang utuh, integral, dan memenuhi fungsi kekhalifahan kemanusiaan universal di bumi, berpangkal dari kebebasan nurani. Yaitu, kebebasan dari setiap bentuk pemaksaan, sekalipun pemaksaan yang dilakukan

\footnotetext{
${ }^{32}$ Nurcholish Madjid, Masyarakat Religius (Jakarta: Paramadina, 2000), hlm. 46.

${ }^{33}$ Ibid., hlm. 46.

${ }^{34}$ Lihat Madjid, Islam Doktrin Dan Peradaban, hlm. 4; dan Komaruddin Hidayat dan Ahmad Gaus AF (ed.), Passing Over, hlm. 9.
} 
atas nama kebenaran mapan (established truth) — sesuatu yang jelas benar dan baik. $^{35}$

Sebab bagi Cak Nur, kebebasan memilih dan menentukan sendiri keyakinan pribadi adalah hak yang paling asasi pada manusia. Itulah sebabnya mengapa agama dan keyakinan tidak boleh dipaksakan, sebab pemaksaan dalam hal itu akan dengan sendirinya menghilangkan nilai keyakinan itu sendiri. Hendaknya setiap pribadi memilih keyakinannya dengan bebas dan penuh tanggung jwab atas segala resiko dan konsekuensinya. ${ }^{36}$

Keutuhan hidup manusia dimulai dengan adanya kebebasan padanya untuk menerima atau menolak sesuatu yang berkaitan erat dengan nilai hidup pribadinya yang mendalam. Lebih-lebih setelah mencapai tingkat peradaban seperti yang ditampilkan sejak kurang lebih 15 abad terakhir ini, kemanusiaan universal haruslah dipandang sebagai telah dewasa dan matang dalam mengambil keputusan tentang kehidupan nuraninya. Seorang manusia harus dibiarkan bebas bereksperimen dengan kebebasan hati nuraninya sendiri: kebebasan untuk menerima atau menolak sesuatu-baik dan buruk, benar dan salah-dengan kesediaan menanggung risikonya sendiri, juga baik dan buruk, bahagia dan sengsara.

Sebab yang benar telah jelas berbeda dari yang salah, yang sejati telas jelas berlainan dari yang palsu. Masalah prinsipil ini terkait erat dengan firman Allah bahwa tidak boleh ada pemaksaan dalam agama. Untuk kita renungkan lebih lanjut dan mendalam, bahwa:

"Tidak boleh ada paksaan dalam agama. Kebenaran telah nampak nyata (perbedaannya) dari kesesatan. Maka barang siapa menolak kekuatan tiranik (thaghut) dan beriman kepada Allah, ia sungguh telah berpegang dengan tali (pegangan hidup) yang kuat, yang tidak akan putus. Allah Maha Mendengar dan Maha Mengetahui”. (QS. 2: 256)

Perhatikan, betapa prinsip tidak boleh ada pemaksaan dalam agama itu dikaitkan dengan penegasan bahwa yang benar telah jelas berbeda dari yang salah, sehingga manusia dengan kebebasan dan kebersihan nuraninya tentu mampu

35 Madjid, Masyarakat Religius, hlm. 47-48.

${ }^{36}$ Madjid, Islam Doktrin, hlm. 564. 
mengenali dan menangkapnya. Juga perhatikan, betapa menolak kekuatan tiranik dikaitkan dengan iman kepada Allah, atau, dari sudut lain, iman kepada Allah dikaitkan dengan sikap menolak dan melawan kekuatan tiranik. Dan akhirnya perhatikan, bahwa ayat ditutup dengan penegasan bahwa Allah adalah Maha Mendengar dan Maha Mengetahui. Artinya, berkenaan dengan prinsip dalam ayat ini, bahwa Allah mengetahui detak hati nurani seseorang, apakah ia menerima dan melakukan sesuatu karena pilihannya yang bebas dan tulus, ataukah karena keadaan terpaksa.

Karena begitu asasinya kemerdekaan nurani ini, maka biarpun seorang yang mengetahui dengan pasti tentang apa yang benar dan yang sejati-seperti para nabi dan rasul - tidak diperkenankan Allah memaksakan pengetahuannya itu kepada orang lain. ${ }^{37}$ Mereka yang meyakini suatu kebenaran dan kesejatian, serta meyakini pula bahwa kebenaran dan kesejatian itu akan membawa keselamatan dan kebahagiaan orang lain, dibolehkan hanya sampai tingkat memberi peringatan kepada orang lain, dan hanya sampai kepada tingkat mengajaknya dengan hikmah-kebijaksanaan, keterangan persuasif dengan penuh pengertian, dan argumentasi dialektis yang meyakinkan. ${ }^{38}$

Sampai disini, dengan semua argumen di atas, kita menemukan nada inklusif dalam pembacaan Cak Nur terhadap makna kebebasan. Kebebasan menjadi salah dari hak asasi yang sangat eksklusif, dalam arti sangat istimewa yang dianugerahkan Tuhan secara khusus kepada setiap manusia tanpa memandang latar belakang suku, ras, etnis, bahasa dan budaya, bangsa, keyakinan, dan agamanya. Dengan kebebasan primordial inilah setiap manusia memiliki kebebasan untuk mengekspresikan hak-haknya sesuai dengan pilihan mereka masing-masing dan tak seorangpun dapat memaksakan kehendaknya atas nama apapun, sekalipun atas nama keyakinan, agama, dan Tuhannya.

\section{Demokrasi}

Dalam pandangan Cak Nur, persoalan demokrasi bukan hanya menjadi salah satu prinsip krusial yang dititahkan dalam doktrin-doktrin fundamental

${ }^{37}$ Budhy Munawar Rachman (peny.), Ensiklopedi Nurcholish Madjid Vol 2 (Jakarta: Paramadian, 2006), hlm. 1452-1453.

38 Madjid, Masyarakat Religius, hlm. 49. 
Islam, tapi juga dipraktekkan secara menakjubkan oleh Nabi Muhammad Saw sendiri bersama para sahabat-sahabatnya. Cak Nur merujuk kepada generasi awal, al-salaf al-shalih (generasi klasik yang saleh) dalam mencari bahan-bahan historis untuk autentifikasi pandangan keagamaan yang memancar dalam tatanan kehidupan sosial seperti keadilan, keterbukaan, dan demokrasi. Dalam konteks ini, Cak Nur mengutip pandangan dan penilaian sosiolog agama kontemporer Robert N. Bellah terhadap praktek kehidupan sosial-politik Nabi Muhammad Saw dan sahabat-sahabatnya:

"Tidak diragukan lagi bahwa, di bawah pimpinan Muhammad, masyarakat Arabia telah membuat lompatan ke depan luar biasa dalam kompleksitas sosial dan kapasitas politik. Ketika struktur yang telah mulai terbentuk di bawah pimpinan Nabi Muhammad dikembangkan oleh para khalifah pertama untuk menyediakan dasar penyusunan imperium dunia, hasilnya ialah sesuatu yang untuk masa dan tempatnya luar biasa modern. Ia modern dalam hal tingkat komitmen, keterlibatan dan partisipasi yang tinggi, yang diharapkan dari semua lapisan anggota masyarakat. Ia modern dalam hal keterbukaan posisi kepemimpinannya terhadap kemampuan yang dinilai menurut ukuran-ukuran universal, dan dilambangkan dalam usaha untuk melembagakan kepemimpinan puncak yang tidak bersifat warisan. Meskipun pada saat-saat permulaan beberapa kendala tertentu muncul untuk menghalangi komunitas (Muslim) dari sepenuhnya mewujudkan prinsip-prinsip tersebut, komunitas itu berhasil juga mewujudkannya, cukup dekat kepada penyajian suatu contoh bangunan komunitas nasional modern, yang lebih baik daripada yang bisa dibayangkan. Usaha orang-orang muslim modern untuk melukiskan komunitas (Islam) pertama itu sebagai contoh sesungguhnya bagi nasionalisme partisipan yang egaliter sema sekali bukanlah suatu fabrikasi ideologi yang tidak historis". 39

Mengenai kajian Bellah tersebut, Cak Nur menanggapi bahwa sebagai masyarakat egaliter partisipatif, masa klasik Islam itu menyerupai benar gambaran sebuah masyarakat yang adil, terbuka dan demokratis seperti dalam konsepkonsep sosial-politik modern. Sifatnya yang egaliter dan partisipasif itu telah nampak dalam berbagai keteladanan Nabi sendiri, demikian pula dalam keteladanan para khalifah yang bijaksana (al-Khulafa al-Rasyidun), bahkan masih

\footnotetext{
39 Madjid, Islam Doktrin Dan Peradaban, hlm. 114.
} 
terasa denyut nadinya sampai kepada masa-masa selanjutnya yang cukup jauh seperti masa Khalifah Umar Ibn 'Abd al-Aziz dari Dinasti Umawi, dan malahan masa Khalifah al-Qadir Billah dari Dinasti Abbasi pada saat-saatnya yang terakhir sebelum mengalami kehancuran. ${ }^{40}$

Namun yang menarik, bagi Cak Nur prinsip-prinsip demokrasi yang sudah dipraktekkan pada masa era Rasul Saw dan para sahabatnya itu bersandar pada prinsip keimanan dalam Islam. Jika iman membawa konsekuensi pemutlakan hanya kepada Allah, Tuhan Yang Maha Esa, tidak ada lawan yang lebih prinsipil terhadap iman selain sikap memutlakan sesuatu selain Tuhan, termasuk terhadap sesama manusia. $^{41}$

Karena itu, iman kepada Allah menuntut agar segala perkara antar manusia diselesaikan melalui musyawarah, yang dengan sendirinya adalah suatu proses timbal balik (reciprocal) antara para pesertanya, dengan hak dan kewajiban yang sama. Deskrispi mengenai masyarakat yang beriman sebagai masyarakat musyawarah sedemikian mengesankan bagi orang-orang muslim pertama, sehingga surah dalam Al-Qur'an yang memuat deskripsi itu disebut surah Syura atau musyawarah (Dalam sistem Al-Quran, hal yang menonjol itulah yang biasanya digunakan sebagai dasar untuk memberi nama surat yang bersangkutan. Karena itu jelas sekali bahwa musyawarah merupakan salah satu tema pokok dan sentral ajaran Al-Quran). ${ }^{42}$

Maka bagi Cak Nur, demokrasi, sebagaimana dikehendaki oleh logika musyawarah itu sendiri, senantiasa menuntut dari masing-masing pihak yang bersangkutan kesediaan secara tulus bertemu dalam titik kesamaan kebaikan bagi semua, dalam semangat memberi dan mengambil yang dijiwai oleh pandangan kemanusiaan yang optimis dan positif. Oleh karena itu pula, demokrasi dengan musyawarah yang benar sebagai landasannya itu tidak akan terwujud tanpa pandangan persamaan manusia atau egalitarianisme yang kuat dan akan kandas

\footnotetext{
${ }^{40}$ Ibid., hlm. 114-115.

41 Madjid, Islam Doktrin Dan Peradaban, hlm. 118.

${ }^{42}$ Lihat Rachman, Ensiklopedi Nurcholish Madjid Vol 3, hlm. 2138.
} 
oleh adanya stratifikasi sosial yang kaku dan a priori dalam sistem-sistem paternalistik dan feodalistik. $^{43}$

Berdasarkan sketsa di atas, meskipun Cak Nur bertolak dari prinsip keimanan dan keteladanan hisoris kenabian, ia dengan fasih menyuarakan demokrasi secara inklusivistik: bahwa di hadapan sebuah negara yang menganut sistem demokrasi, maka setiap orang mempunyai hak dan kebebasan yang sama dalam menyampaikan aspirasi dan tuntunan keadilan secara terbuka dan demokratis tanpa memandang latar belakang suku, ras, golongan, budaya, bahasa, keyakinan, dan agamanya. Semua orang, sebagai bagian dari masyarakat yang demokratis, terbuka, dan adil, harus berpartisipasi dengan penuh komitmen dan tanggung jawab demi kebaikan semua masyarkat, demi kemaslahatan semua warga negara secara equal.

\section{Kesimpulan: Signifikansi Dakwah Inklusif Nurcholish Madjid}

Dari berbagai eskposisi di atas, kita telah melihat bagaimana Cak Nur melakukan konstruksi terhadap makna Islam secara inklusif dalam dua level: inklusif secara substantif-doktrinal dan inklusif secara substantif-sosial. Pada level substantif-doktrinal, bagi Cak Nur, Islam merupakan sebuah ketundukan, kepatuhan, sekaligus kepasrahan kepada Tuhan Yang Maha Esa dalam pengabdian yang tulus ikhlas secara privat; Sehingga ketundukan dan kepatuhan ini mencakup keimanan sekaligus mengimplementasikannya dalam bentuk amal kebajikan tanpa harus dibatasi dengan emblem-emblem budaya, suku, ras, bangsa, golongan, keyakinan, paham, dan agamanya.

Pemahaman Islam pada tataran substantif-doktrinal ini bukan tanpa alasan. Secara tidak langsung, pada orang-orang Islam atau kaum muslim sendiri, Cak Nur menghendaki keberagamaan yang substantif: sebuah semangat dalam mencari kebenaran yang terbuka dan pengabdian kepada Tuhan yang bersifat dinamis, bukan statis. Menjadi orang Islam atau kaum muslim yang sejati itu adalah menumbuhkan sikap aktif dalam proses mendekati Sang Kebenaran sampai selembar nyawa kita ditutup oleh tirai kematian. Jadi agama Islam itu

\footnotetext{
${ }^{43}$ Rachman, Ensiklopedi Nurcholish Madjid Vol 3, hlm. 2135-2136.
} 
menjelma sebuah kategori dinamis dalam proses pencarian hakikat kebenaran yang terbuka, bukan hanya kategori historis-sosiologis. ${ }^{44}$

Namun jangan salah paham, bahwa Cak Nur tentu saja tetap dan sangat mengakui eksistensi agama Islam secara legal-formal, secara institusional. Agama Islam yang telah melembaga sejah 15 abad lalu ini riil dan faktual, benar-benar diakui Cak Nur. Ini merupakan fakta sejarah sebagai identitas komunal umat Islam dan kaum muslim yang tersebar di seluruh dunia, dan tak seorangpun yang akan menafikannya. Tapi Cak Nur ingin agar kita jangan berhenti pada ranah keberagamaan secara formalistik tanpa berupaya melakukan pencarian kebenaran secara substantif. Sebab hakikat hidup itu sendiri adalah sebuah proses mendekat kepada Allah sabagai Sang Kebenaran Hakiki yang mengasumsikan sebuah gerak dinamis pengabdian tanpa henti, bukan keadaan statis dengan menjadi seorang yang beridentitas Islam atau muslim semata.

Selanjutnya, dengan pemaknaan secara substantif itu pula, Cak Nur menjadikan inklusif Islam sebagai basis kerukunan hidup di antara beragam umat beragama yang berbeda dalam konteks Indonesia. Bagi Cak Nur, inklusivisme juga merupakan sebuah sikap yang bertujuan untuk menumbuhkan sikap kejiwaan yang melihat adanya kemungkinan orang lain itu benar. Ketika dalam agama disebutkan bahwa manusia itu diciptakan dalam keadaan fitrah, maka setiap orang pada dasarnya suci dan benar. Potensi untuk benar adalah primer. ${ }^{45}$ Karena itu, salah satu solusi yang menurut Cak Nur mendesak dan penting, yaitu mengubah 'teologi buruk sangka' dan menjadi 'teologi inklusif' .

Dalam konteks inilah, bila kita memasuki konstruksi makna Islam Cak Nur pada level substantif-sosial, kita akan menemukan signifikansi wacana inklusif dalam tataran praksis. Dengan pijakan Islam inklusif secara substantifdoktrinal, Cak Nur kemudian hendak membawa semua nilai-nilai kebajikan dalam Islam pada tataran praksis sosial secara inklusif pula: semua nilai-nilai kebajikan dalam Islam yang hendak dibawa ke ruang publik masyarakat Indonesia mesti bersifat inklusif, substantif dan objektif, menyentuh dan merengkuh semua

\footnotetext{
${ }^{44}$ Madjid, Dialog Keterbukaan, hlm. 255.

${ }^{45}$ Zuhairi Misrawi, Al-Qur'an Kitab Toleransi (Jakarta: Fitrah, 2007), hlm. 200-201.
} 
lapisan masyarakat yang berasal dari beragam budaya, kelompok, keyakinan, dan agama. Seluruh nilai-nilai kebajikan yang berada dalam Islam tidak boleh bersifat eksklusif, yakni hanya bermanfaat untuk kalangan umat Islam semata, tapi harus bersifat inklusif, harus membawa manfaat yang sebesar-besarnya dan seluasluasnya bagi umat manusia, bagi kemanusiaan universal.

Sampai disini, mungkin kita bertanya: mengapa nilai-nilai prinsipil ajaran Islam harus diterjemahkan dulu ke dalam bahasa yang inklusif? Paling tidak ada dua jawaban besar. Pertama, ini yang paling mendasar dan seringkali diulang oleh Cak Nur, sebab misi utama Islam adalah membawa kebaikan untuk semua orang, bahkan semesta alam; Misi general Islam adalah rahmatan lil 'alamin. Jadi kebajikan yang disemaikan oleh Islam bukan untuk umat Islam sendiri saja, tapi juga untuk kebaikan orang lain, untuk kebaikan seluruh umat manusia. Agar dapat menyentuh orang banyak sekaligus dirasakan seluas-luasnya oleh umat manusia, maka prinsip-prinsip kebajikan Islam itu perlu dibingkai dalam bahasa yang terbuka yang dapat diakses oleh semua lapisan sosial masyarakat yang berbeda. ${ }^{46}$

Kedua, dalam konteks masyarakat Indonesia yang bercorak multi: multi bahasa, budaya, ras, suku, paham, golongan, dan agama, maka agar tidak terjadi konflik kepentingan di antara berbagai perbedaan tersebut, nilai-nilai Islam tersebut mesti diformulasikan ke dalam bahasa yang inklusif yang dapat diterima oleh semua keragaman masyarakat Indonesia. Agar nilai-nilai kebajikan dalam Islam dapat berguna bagi umat manusia secara inklusif-universal, maka Cak Nur melakukan substansiasi terhadap sebagian besar nilai kebajikan Islam yang bersifat substantif ke dalam tataran objektif, seperti nilai keadilan, kemanusiaan, kesetaraan, kebebasan, hak asasi manusia, kedamaian, etika sosial, demokrasi, dan lain-lainnya. Semua nilai-nilai kebajikan ini terdapat dalam agama Islam tetapi bersifat inklusivistik: dapat meliputi semua orang dari berbagai lapisan sosial, budaya, suku, golongan, paham, dan agamanya.

Dengan kata lain, seluruh masyarakat bangsa Indonesia tanpa melihat latar belakang sosial, budaya, bahasa, dan agama mereka yang bercorak plural dan berbeda, tetap dapat merasakan kemanfaatan dari nilai-nilai kebajikan Islam yang

\footnotetext{
${ }^{46}$ Ibid.
} 
berwajah inklusif tersebut. Dengan melihat korelasi yang tak terpisahkan antara paradigma inklusif secara substantif-doktrinal dengan substantif pada aras sosial, dan kepiawaian Cak Nur menurunkannya pada level praksis sosial secara konkret, kita tidak bisa menafikan kontribusi Cak Nur bagi masyarakat Indonesia yang berwajah pluralistik dengan paradigma inklusifnya tersebut. 


\section{DAFTAR PUSTAKA}

Al-Isfahani, Al-Raghif. Mufradat al-Quran. Beirut: Dar al-Syamiyah, 1996.

Hardiman, F. Budi. Demokrasi Deliberatif. Yogyakarta: Kanisius, 2009.

Hidayat, Komaruddin dan Ahmad Gaus AF (ed.). Passing Over. Jakarta: Gramedia Pustaka Utama, 2001.

Kuntowijoyo. Identitas Politik Umat Islam. Bandung: Mizan, 1997. . Islam Sebagai Ilmu. Jakarta: Teraju, 2004.

Madjid, Nurcholish. Pintu-Pintu Menuju Tuhan. Jakarta: Paramadina, 1995. . Dialog Keterbukaan. Jakarta: Paramadina, 1998. . Islam Agama Peradaban. Jakarta: Paramadina, 2000. . Islam Kerakyatan Dan Keindonesiaan. Bandung: Mizan, 1996. . Pesan-Pesan Takwa. Jakarta: Paramadina, 2000. . "Mewujudkan Masyarakat Madani di Era Reformasi” Jurnal Titik

Temu Vol. 1 Nomor 2, Januari-Juni 2009. . dkk. Fiqih Lintas Agama. Jakarta: Paramadina, 2004.

Misrawi, Zuhairi. Al-Qur'an Kitab Toleransi. Jakarta: Fitrah, 2007.

Nata, Abuddin. Peta Keragaman Pemikiran Islam Di Indonesia. Jakarta: Raja Grafindo Persada, 2001.

Nurcholish Madjid, Masyarakat Religius (Jakarta: Paramadina, 2000.

Rachman, Budhy Munawar. Argumen Islam Untuk Pluralisme. Jakarta: Grasindo, 2010.

(peny.). Ensiklopedi Nurcholish Madjid Vol 2. Jakarta: Paramadian, 2006. (peny.). Ensiklopedi Nurcholish Madjid Vol 3. Jakarta: Paramadian, 2006.

Shihab, M. Quraish. Tafsir Al-Misbah Vol. 7. Jakarta: Lentera Hati, 2002. 